\title{
ARTICLE
}

\section{SPATIAL DISTRIBUTION OF SUBSIDENCE IN HANOI DETECTED BY JERS-1 SAR INTERFEROMETRY}

\author{
TRAN Van Anh*, Shinji MASUMOTO*, Venkatesh RAGHAVAN** and Kiyoji SHIONO* \\ * Graduate School of Science, Osaka City University, 3-3-138 Sugimoto, Sumiyoshi-ku, \\ Osaka 558-8585, Japan. E-mail: vananh@sci.osaka-cu.ac.jp \\ **Graduate School for Creative Cities, Osaka City University, 3-3-138 Sugimoto, Sumiyoshi- \\ ku, Osaka 558-8585, Japan
}

(Received: 13 May 2006; Accepted 28 November 2006)

\begin{abstract}
Hanoi City, the capital of Vietnam is located in a flood plain of the Red River with average elevation less than $20 \mathrm{~m}$. Water demand due to the rapid increase of population has led to too much groundwater exploitation, which has caused a remarkable land subsidence over the whole area of the city. The conventional surveying methods have been used to monitor the subsidence. However it requires a time consuming and intensive labor to survey densely over a large area. Therefore, differential radar interferometry was used here as a complementary technique. To detect the spatial extent of subsidence in the city area, we applied the so-call three-pass differential interferometry method that detects terrain change phase from three images acquired at different times. We used three JERS-1 SAR L-band images covering the area of Hanoi City in the period 1995-1998 to generate two interferometric pairs or interferograms. The data was analyzed focusing on the urban area and the suburbs with the area of about $400 \mathrm{~km}^{2}$. Although the differential interferometric phase was noisy in the Red River, the Tay Lake and the vegetated area outside of the city, signatures of ground movements were detected clearly within the urban area. The estimated rate of subsidence is about $2.7 \mathrm{~cm} /$ year near the Tay Lake and the Red River, and $3.3 \mathrm{~cm} /$ year at Minh Khai near the south east part of the urban area. This result is consistent with the result of the leveling survey in 1994 and 1995 that indicated rapid subsidence of about 1.3-1.8 cm/year at benchmarks near the Tay Lake and the Red River. Because of low coherence at the southern part of the city, JERS-1 data could not determine subsidence near Phap Van and Van Dien where significant subsidence was observed by the leveling survey. Thus, we concluded that results derived from the area of high coherence confirm the capability of L-band images for monitoring of subsidence in Hanoi City.
\end{abstract}

Key words : Remote sensing, Leveling, L-band, DInSAR, Three-Pass Method

\section{Introduction}

Terrain change happens all over the world at different rates. Natural disasters such as earthquakes, floods, volcanic eruptions and landslides cause large scale of terrain change. Aerial photographs and satellite images with high spatial resolution are often used to estimate the terrain change, but there is a limit of ability to detect the local and subtle change such as gradually proceeding subsidence.

Differential SAR Interferometry (DInSAR) is a technique to estimate small surface deformation using three or more SAR images taken from the approximately same positions at different times. The DInSAR is extremely sensitive to small relative changes in elevation occurring in the time interval between the passes. One of the most promising applications of DInSAR is the measurement of small surface deformations with accuracy to few millimeters. It allows rapid and precise determination of relative vertical and horizontal displacement.

DInSAR was first applied on Seasat images at JPL to measure small elevation changes over large swaths $50 \mathrm{~km}$ in Imperial Valley, California (Gabriel and Goldstein, 1989). Since then a lot of scientists have applied this technique to the measurement of geophysical process including dynamics of glacier and ice motion (Goldstein et al., 1993), land subsidence in mining areas (Ferreti et al., 2000), landslides in mountainous areas (Rott et al., 2000), and detection of volcanic deposit on the Mount Mayon, Philippine (Honda et al., 2003).

From these capabilities, we tried to detect land subsidence in Hanoi City, Vietnam by the three-pass differential interferom- 
(a)

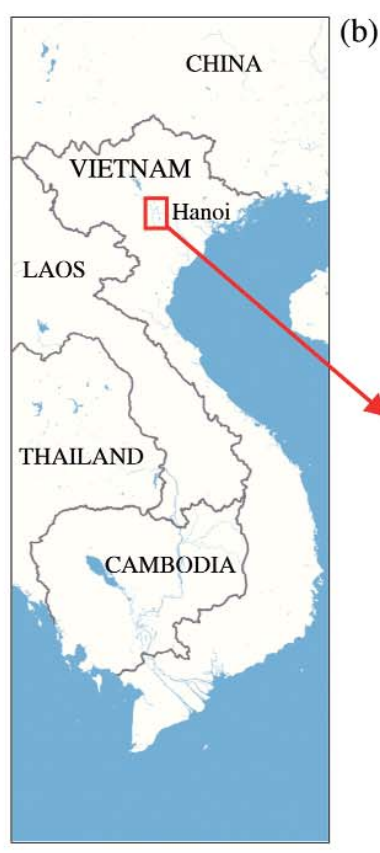

(b)

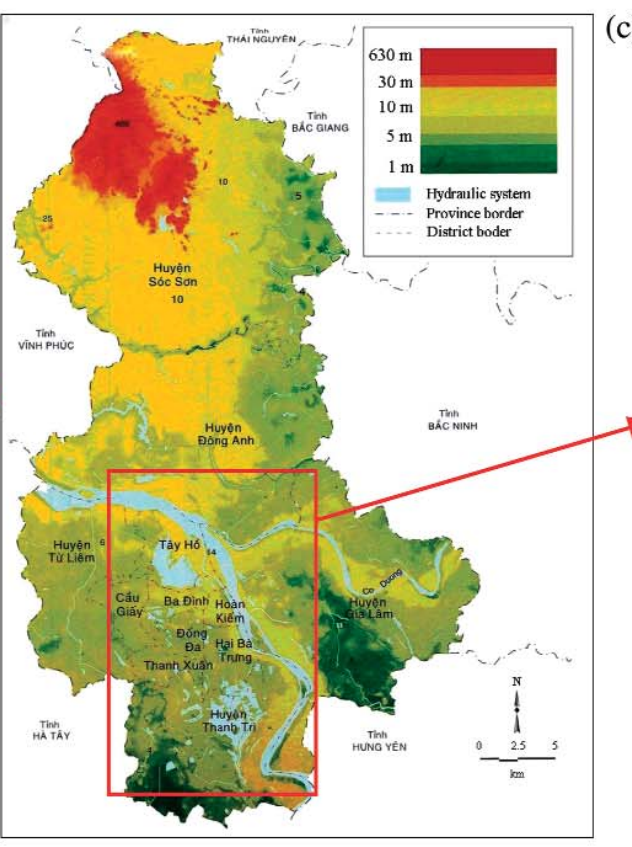

(c)

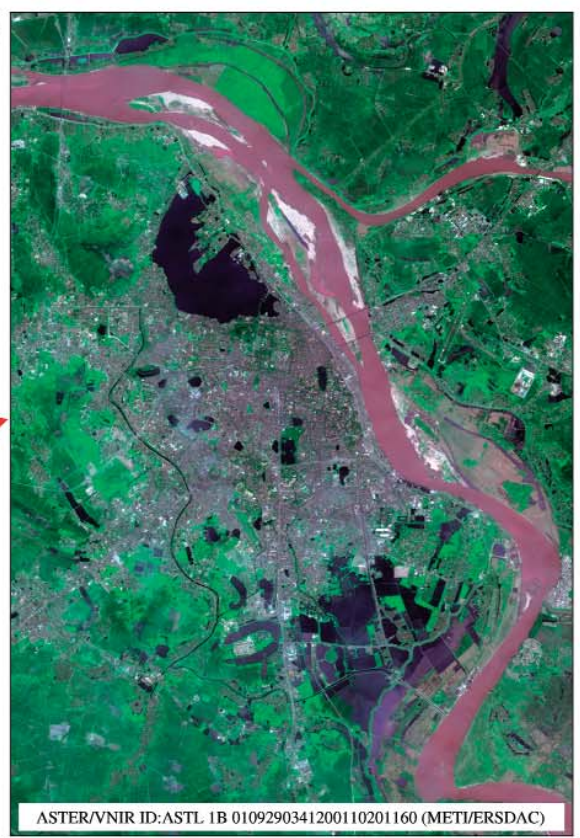

Figure 1. Study area. (a) Location of studied area, (b) The topographic map of 1:10000 (VTGEO: Institute of Geology, Vietnam National Centre for Natural Science and Technology), (c) ASTER image of Hanoi City (METI/ERSDAC, Japan).

etry method. Raucoules and Carnec (1999) generated differential interferograms from ERS-1/2 SAR C-band data to detect subsidence over the urban area of Hanoi City using several pairs of interferometric images. They detected signatures of ground movement as much as about $1.5 \mathrm{~cm}$ height variation in noisy differential interferograms. JERS-1 SAR radar was used in our experiment for subsidence detection of Hanoi area. The JERS-1 SAR L-band pulse with a long wave length of $23.513 \mathrm{~cm}$ is less influenced by vegetation and water vapor in the atmosphere than ERS-1/2 C-band pulse. We expected that the decorrelation due to vegetation and water vapor is reduced rather than the case of Raucoules and Carnec (1999).

\section{Subsidence detection of Hanoi City, Vietnam}

\subsection{Overview of geography and groundwater exploitation in \\ Hanoi}

Hanoi City, the second largest City in Vietnam is situated at latitudes $20^{\circ} 53^{\prime}-21^{\circ} 23^{\prime} \mathrm{N}$ and longitudes $105^{\circ} 44^{\prime}-106^{\circ} 02^{\prime}$ E within the Red River Delta (Figure 1). Hanoi City is surrounded by six provinces; Thai Nguyen in the north, Bac Ninh and Bac Giang in the east, Hung Yen in the southeast, Ha Tay in the south and southwest, and Vinh Phuc in the west. Hanoi City is spread over a total area of $900 \mathrm{~km}^{2}$ with a population of 2.7 million. The topography is flat with elevations below $20 \mathrm{~m}$ except for the Tamdao hills up to $462 \mathrm{~m}$ in heights. Our research focuses on the urban area of Hanoi City and its suburbs. The urban area is underlain by unconsolidated sediments that consist of marine, lacustrine and alluvial materials overlaying a coarse (a)

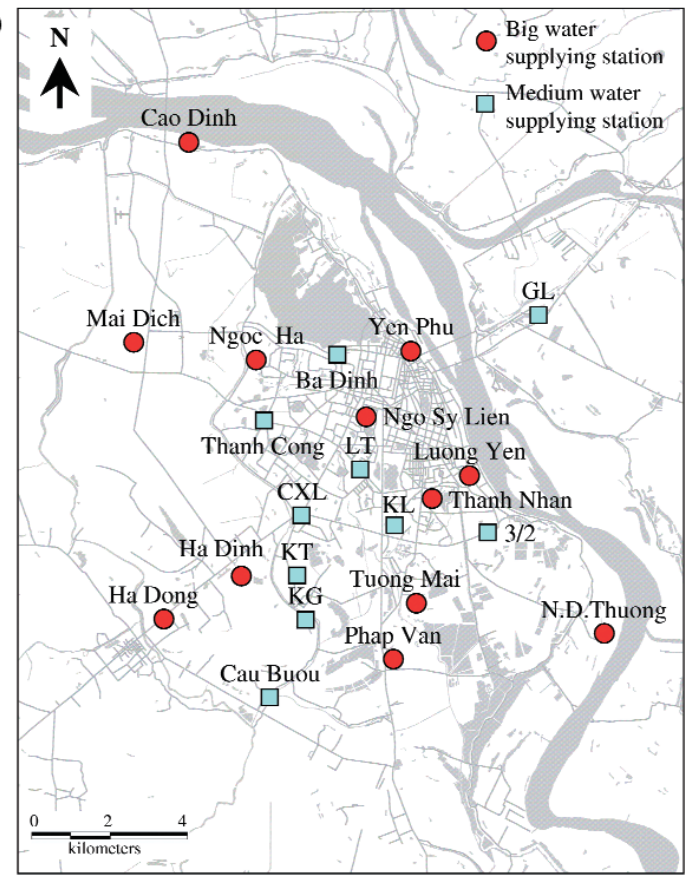

(b) $10^{4} \mathrm{~m}^{3} /$ day

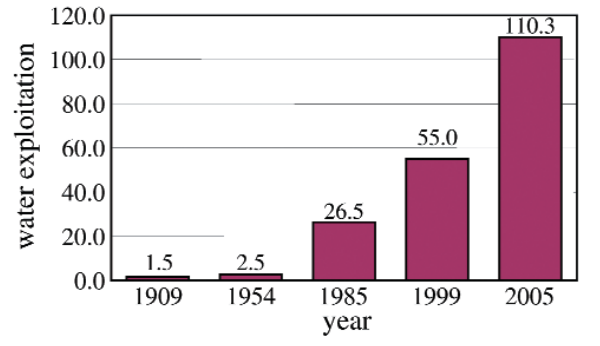

Figure 2. Water supply in Hanoi City.

(a) Water supply stations. (b) History of water exploitation from 1909 to 2005 . 
sand and gravel aquifer.

In the urban area of Hanoi City, water supply for domestic purposes and industries is mainly derived from groundwater. Groundwater is pumped up from the coarse sand and gravel aquifer at 10 big well fields and other small stations with the total number of 150 wells. The ground water was exploited from the beginning of 20th century and increased significantly in amount. Figure 2 shows the plan of water supply stations in the urban area and the water exploitation chart from 1909 to 2005 based on investigation data (Nguyen Trung Thong and Nguyen Van Dan., 2005). Because of the open policies for economic development since 1985, the Vietnamese economy started to grow strongly and therefore the demand for water forced the pumping rate to accelerate. The rate increased up to about $1,103,000 \mathrm{~m}^{3} /$ day in 2005 from $15,000 \mathrm{~m}^{3}$ /day in 1909. The excessive extraction of groundwater has caused both water level decline and land subsidence in the urban area.

\subsection{Data sources}

We used three JERS-1 SAR L-band images acquired in 1995 and 1998:

Image-1 : 1995/09/18

Image-2 : 1995/08/05

Image-3 : 1998/09/22

for the three-pass method of differential interferometry analysis (Figure 3). JERS-1 is the Japanese Earth Resources satellite that was launched on February $11^{\text {th }} 1992$ and terminated on October $12^{\text {th }} 1998$. The nominal altitude is $568 \mathrm{~km}$ and the repeat period is 44 days. JERS-1 SAR used L-band pulses of $\lambda=23.513 \mathrm{~cm}$ in wavelength and the off-nadir angle is 35 degrees. JERS-1 SAR images over Hanoi City were provided as NASDA facility raw images. They were processed along range and azimuth to get the files called Single Look Complex (SLC). Single look complex uses all the signal returns from a ground target to create a single image. The SLC image has slant range pixel spacing of $8.78 \mathrm{~m}$ and an azimuth pixel spacing of $4.51 \mathrm{~m}$. The data are stored as a complex array of two-dimensional elements in a 4-bytes length for each of the real and imaginary parts. One complex scene is composed of 5,546 range elements and 15,850 lines.

We applied the three-pass differential interferometry method to three complex SAR data for subsidence detection in Hanoi area. Two interferograms: $\varphi_{1-2}$ from Images-1 (master) and Image-2 (slave), and $\varphi_{1-3}$ from Image-1 (master) and Image3 (slave) were created. The first interferogram $\varphi_{1-2}$ is used as the topographic reference to extract the deformation phase that is assumed to be included in the second one $\varphi_{1-3}$. Figure 4 summarizes basic information on three SAR images over Hanoi area and interferometric pairs. All the baseline's components are evaluated from orbit data.

As the data processing software, we used GAMMA that

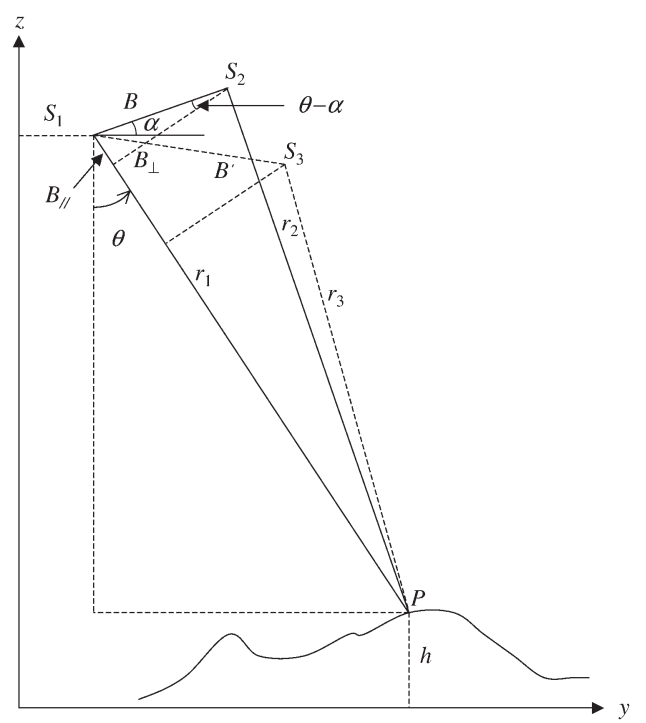

Figure 3. Spatial relationship of three satellites and a ground point $\mathrm{P}$ in the three-pass interferometry.

\begin{tabular}{|lrr|}
\hline \multicolumn{1}{|c}{ Date } & \multicolumn{1}{c}{$1995 / 08 / 05 / 18$} & $1998 / 09 / 22$ \\
Baseline & $104.0 \mathrm{~m}$ & $954.5 \mathrm{~m}$ \\
Perpendicular baseline & $-39.5 \mathrm{~m}$ & $-434.0 \mathrm{~m}$ \\
Parallel baseline & $-96.2 \mathrm{~m}$ & $-849.7 \mathrm{~m}$ \\
Look angle $\theta$ at the center & $38.75^{\circ}$ & $38.77^{\circ}$ \\
Baseline orientation $\alpha$ & $-28.96^{\circ}$ & $-24.16^{\circ}$ \\
Range $r$ at the center & $716881 \mathrm{~m}$ & $716881 \mathrm{~m}$ \\
Interval & 44 days & 1100 days \\
\end{tabular}

Figure 4. Used interferometric SAR combinations from JERS-1 data.

provides image processing modules in the field of microwave remote sensing (Wegmuller et al., 2001).

\subsection{SAR Interferometry}

Before the interferometric processing of complex SAR data that combines two SLC images into an interferogram, it is necessary to co-register two images at sub-pixel accuracy. We coregistered Image-2 for topographic interferogram and Image-3 for deformation interferogram to the master image Image-1. The co-registration of images was performed by applying the bilinear function that maximizes the local spatial correlation in the real valued image intensity to each small area of $32 \times 32$ pixels throughout the image.

After the coregistration, the multi-look over 2 pixels in range and 6 lines in azimuth was performed to improve the quality of the interferometric phase. After the multi-look for speckle reducing, the resolution became $17.56 \mathrm{~m}$ in range and $27.06 \mathrm{~m}$ in azimuth. The size of the image was reduced to 2,773 pixels in range and 2,640 lines. 
The array of phase differences or interferometric phases is obtained from the multi-looked images, where $u_{1}$ is the complex value at a pixel of the master image

$$
u_{1}=A_{1} e^{i \varphi_{1}}
$$

and $u_{2}$ is the complex value at the corresponding pixel of the slave image

$$
u_{2}=A_{2} e^{i \varphi_{2}}
$$

Then we have

$$
I=u_{1} u_{2}=A_{1} A_{2} e^{i\left(\varphi_{1}-\varphi_{2}\right)}
$$

where $\bar{u}_{2}$ shows the conjugate complex number of $u_{2}$. Therefore the phase difference between corresponding pixel is obtained by

$$
\varphi_{1-2}=\varphi_{1}-\varphi_{2}=\arctan \left(\frac{\operatorname{Im}(I)}{\operatorname{Re}(I)}\right)
$$

The phase difference depicted as a raster image is called an interferogram or fringe image. Figure 5 (a) and (b) show two interferograms: $\varphi_{1-2}$ from Image- 1 and Image- 2 , and $\varphi_{1-3}$ from Image-1 and Image-3, respectively. It is noted that the phase difference can be estimated only in the interval $(-\pi, \pi)$, i.e. the phase is wrapped.

Figure 5 (c) and (d) show coherence images for the first pair of Image-1 and Image-2, and for the second pair of Image-1 and Image-3, respectively. The coherence $\gamma$ is defined as the magnitudes of the complex correlation coefficient by

$$
\gamma=\frac{\sum u_{1} \bar{u}_{2}}{\sum\left|u_{1}\right|^{2} \sum\left|u_{2}\right|^{2}}
$$

where $u_{1}$ and $u_{2}$ are corresponding complex values from the two images after interpolation. Summation in equation (2-5) was performed over each shifting windows of $5 \times 5$ pixels. The coherence is a fundamental quantity for the evaluation of quality of an interferogram. The value lies between 0 and 1 . Zero value means that two images are totally uncorrelated, while one means that there is no change between the repeat passes and no noise. The coherence can be plotted in a graphic image known as coherence map.

According to Madsen and Zebker (1998), the interferogram can be ranked as good quality if pixels with coherence greater than 0.5 covers $80 \%$ of a full scene and more. The pixels with coherence greater than 0.5 cover $89 \%$ of the first image pair for the topographic phase $\varphi_{1-2}$ and $66 \%$ of the second one for the deformation phase $\varphi_{1-3}$. The coherence of the first pair is high all over the area except for the narrow zone along the Red River. This high coherence indicates the similarity of two images acquired at a short interval of 44 days. However, in the coherence map for the second image pair, the zones of low coherence are distributed widely along the Red River and also in the vegetated area surrounding the zone of relatively high coherence including the urban area of Hanoi City. Low coherence of the second pair of images is mainly due to the long elapsed time of three years and further due to water current and vegetation.
Although the coherence is generally low, it is notable that the coherence is exceptionally high in the urban area of Hanoi City. This may be due to constant backscatters of artificial constructions.

Figure 5 (e) and (f) shows the unwrapped interferometric phases $\varphi_{1-2}$ and $\varphi_{1-3}$ for the first image pair and the second one, respectively. GAMMA provides phase unwrapping algorithms to reconstruct the array of full cycle interferometric phases from the array of wrapped ones: Branch Cut algorithm (BC) and Minimum Cost Flow algorithm (MCF). BC developed by Goldstein et al. (1988) implements the phase unwrapping by identifying the locations of all residuals in an interferogram and then connecting the residuals with "branch cuts" to prevent the existence of integration paths that can encircle unbalanced numbers of positive and negative residues. The MCF technique to phase unwrapping is presented by Costantini (1998). This method defines a network consisting of nodes and directed arcs that connect the nodes. In this method for the phase unwrapping problem in the network flow form, a node is associated with each of the local closed paths used to evaluate the residues. The network is not a rectangular network but a triangular irregular network (TIN) which is more flexible, for example in the case of disconnected areas of low coherence. The pixels lie between the network arcs and nodes. When calculating the unwrapped phase by summing along the path, the gradient is adjusted if there is a flow in the arc crossing the path of integration (Wegmuller et al., 2002). Considering that the coherence is generally low for the second image pair, we created the unwrapped interferograms using the Minimum Cost Flow algorithm that is efficient to connect the areas of low coherence more than the Branch Cut algorithm.

\subsection{Differential Interferometry}

The unwrapped interferometric phase $\varphi_{p}$ at a given point is composed of at least two signals that depend on acquisition geometry such as satellite positions and topography, and terrain deformation as follows

$$
\begin{aligned}
& \varphi_{p}=-\frac{4 \pi}{\lambda} B_{/ /}+\frac{4 \pi}{\lambda} \Delta r \\
& B_{/ /}=B \sin (\theta-\alpha)
\end{aligned}
$$

where $B$ is the baseline length, $B_{/ /}$is the baseline component parallel to the look direction, $\theta$ is the look angle, $\lambda$ is the wavelength, $\alpha$ is the angle between the baseline and the horizontal line, and $\Delta r$ represents the displacement in the range.

The three-pass differential interferometry is one of DInSAR method that was firstly proposed by Zebker et al. (1994). As we obtained two unwrapped interferometric phases $\varphi_{1-2}$ and $\varphi_{1-3}$ over the same region, sharing one orbit with each other so that $r$ and $\theta$ remain unchanged, we assumed that the 
(a)

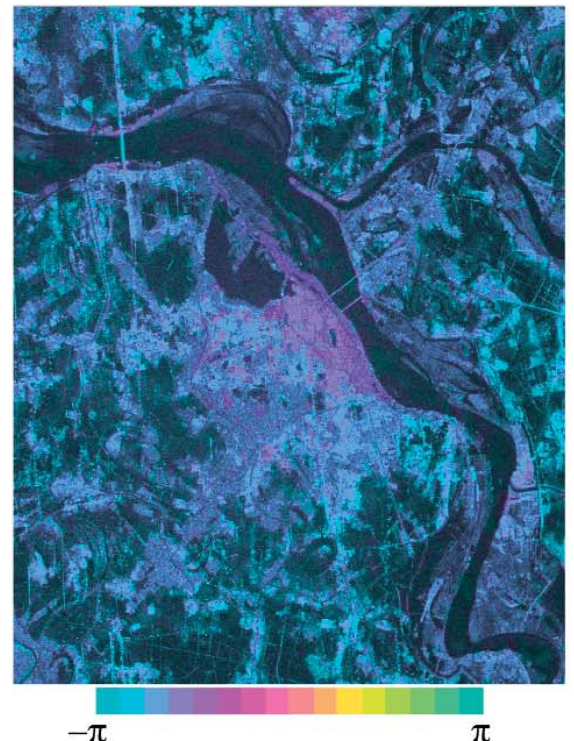

(c)

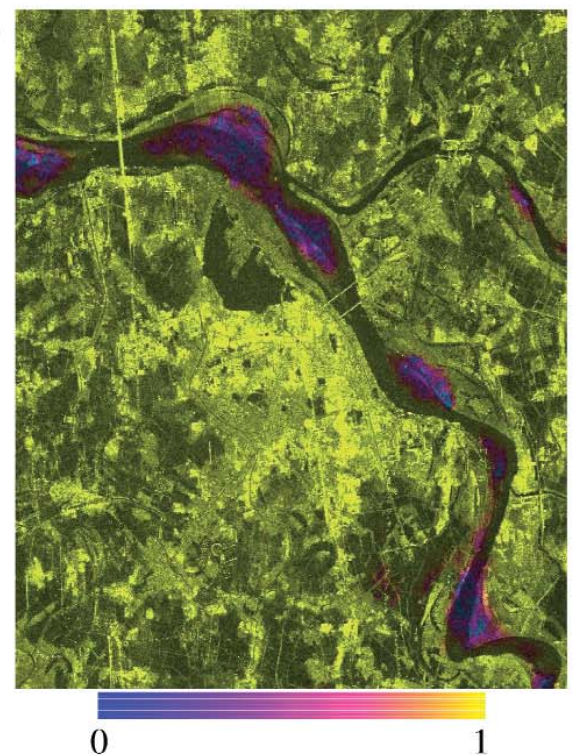

(e)

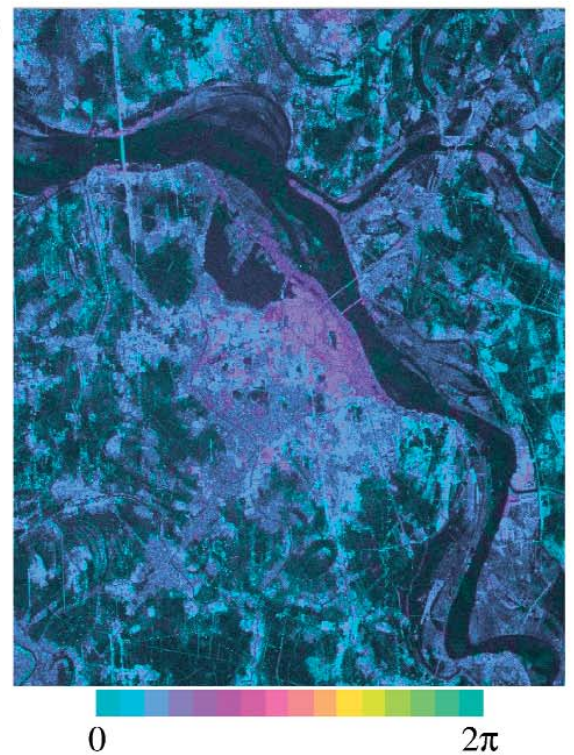

(b)

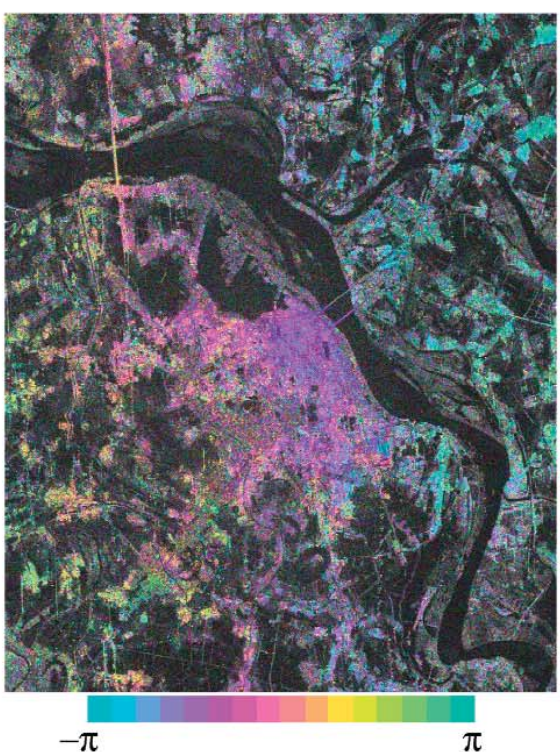

(d)

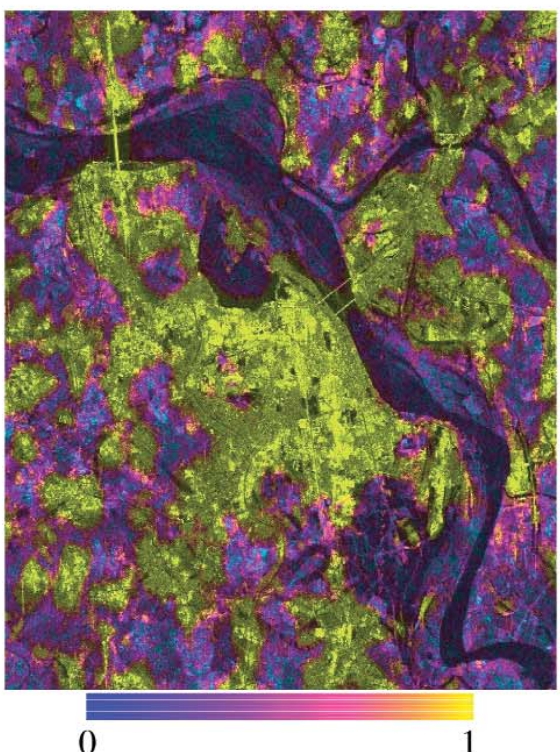

(f)

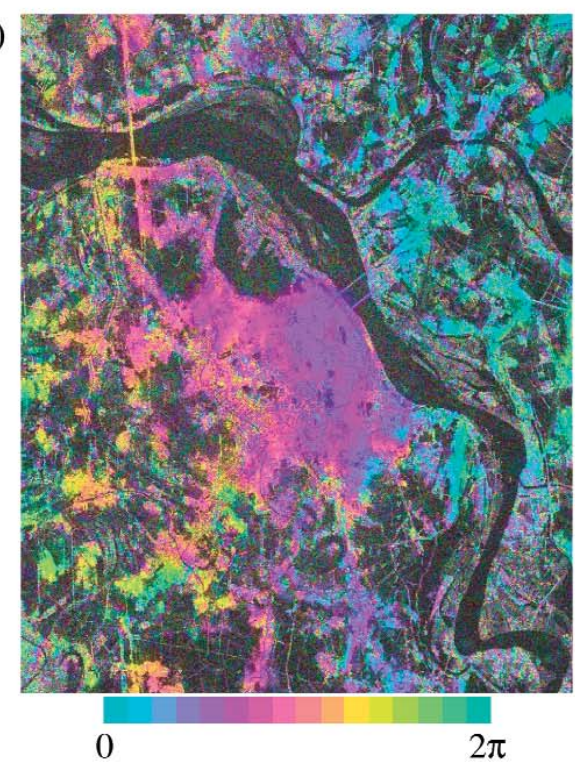

Figure 5. Interferograms and coherence maps generated from Image-1 (1995/09/18), Image-2 (1995/08/05) and Image-3 (1998/09/22). (a) Wrapped interferogram $\varphi_{1-2}$, (b) Wrapped interferogram $\varphi_{1-3}$, (c) Coherence for the pair of Image-1 and 2 ,

(d) Coherence for the pair of Image-1 and 3, (e) Unwrapped interferogram $\varphi_{1-2}$, (f) Unwrapped interferogram $\varphi_{1-3}$. 
first interferometric phase $\varphi_{1-2}$ contains only topographic fringes and the second one $\varphi_{1-3}$ is affected by a surface deformation. Then we have from (2-6)

$$
\varphi_{1-2}=-\frac{4 \pi}{\lambda} B_{/ /}
$$

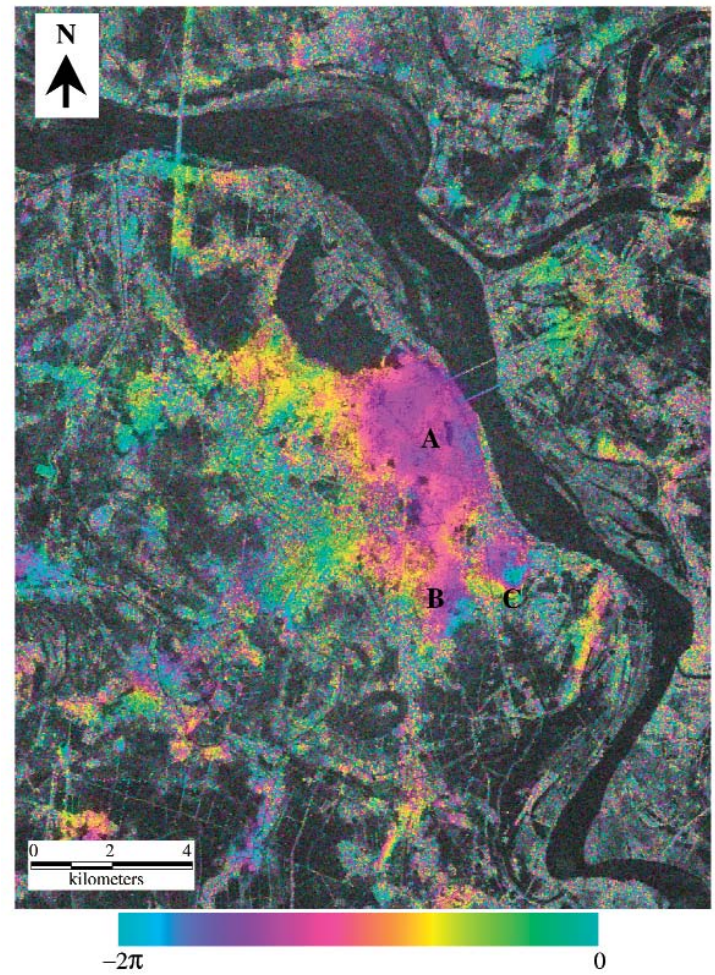

Figure 6. Differential interferogram $\Delta \varphi$. One fringe corresponds to the change of distance along the line of sight by one half of wavelength (11.76 cm with JERS-1 L-band data).

(a)
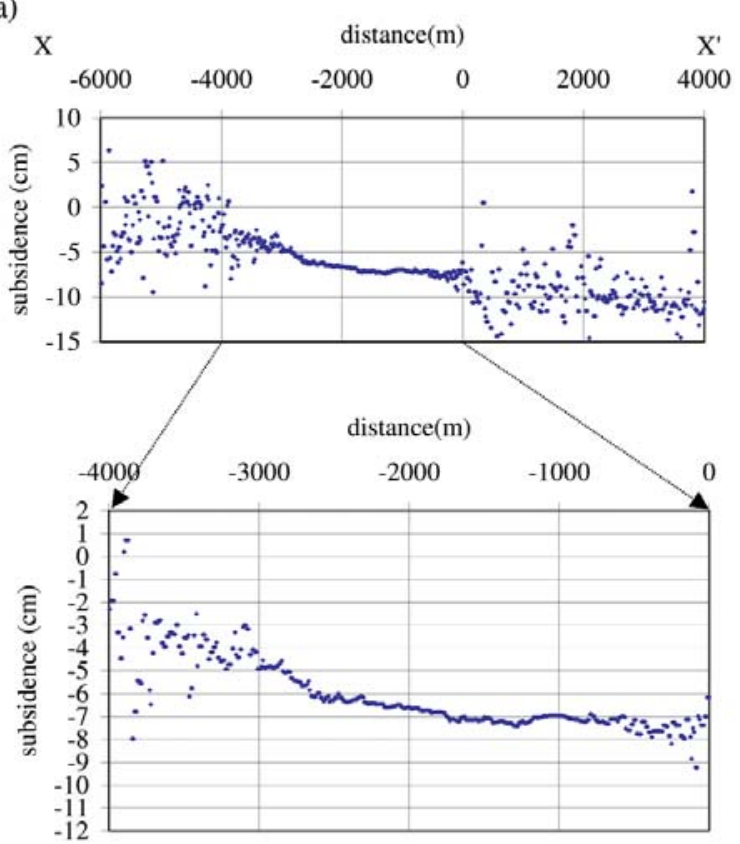

$\varphi_{1-3}=-\frac{4 \pi}{\lambda} B_{/ /}^{\prime}+\frac{4 \pi}{\lambda} \Delta r$

Using the change phase $\Delta \varphi$ defined by

$$
\Delta \varphi=\varphi_{1-3}-\left(\frac{B^{\prime}}{B_{/ /}}\right) \varphi_{1-2}
$$

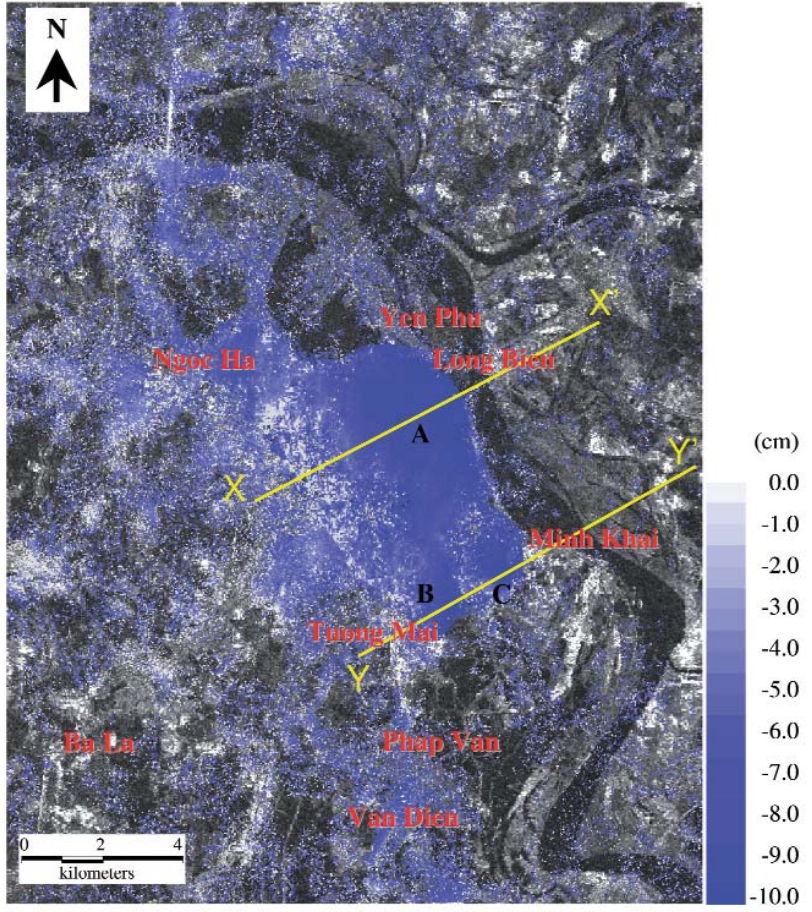

Figure 7. Estimation of total subsidence during the period 1995-1998 based on the assumption that there has been no horizontal displacement. Drawn by GRASS 6.0 with masked noise.

(b)
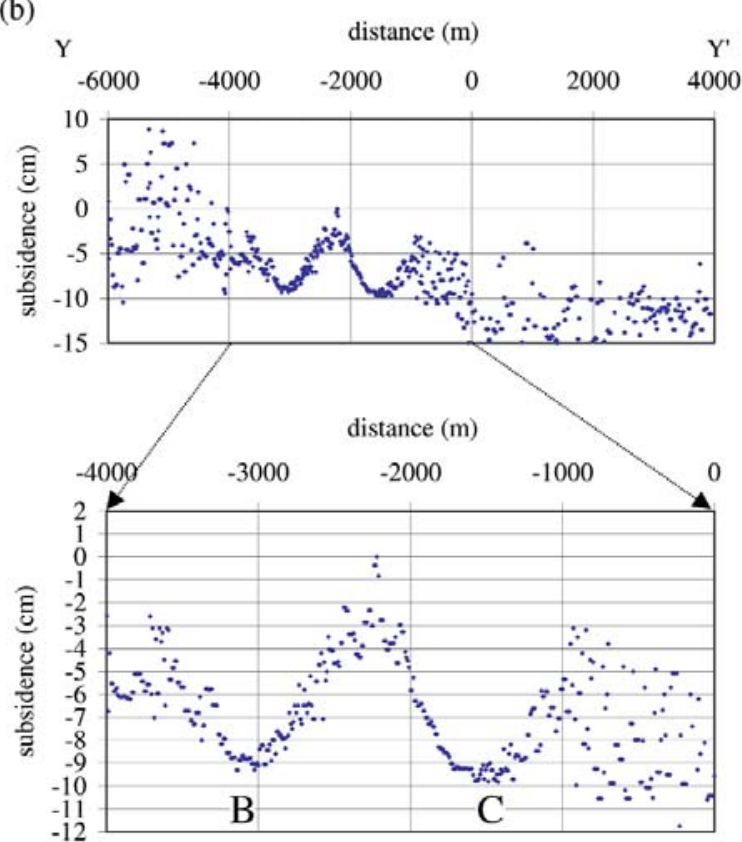

Figure 8. Subsidence along the profiles $X X^{\prime}$ and $Y^{\prime}$ given in Figure 7. (a) Profile $X X^{\prime}$ across the area A, (b) Profile YY' across the areas B and C. Distance is measured in meters from the bank west of the Red River towards $N 60^{\circ} \mathrm{E}$ direction. 


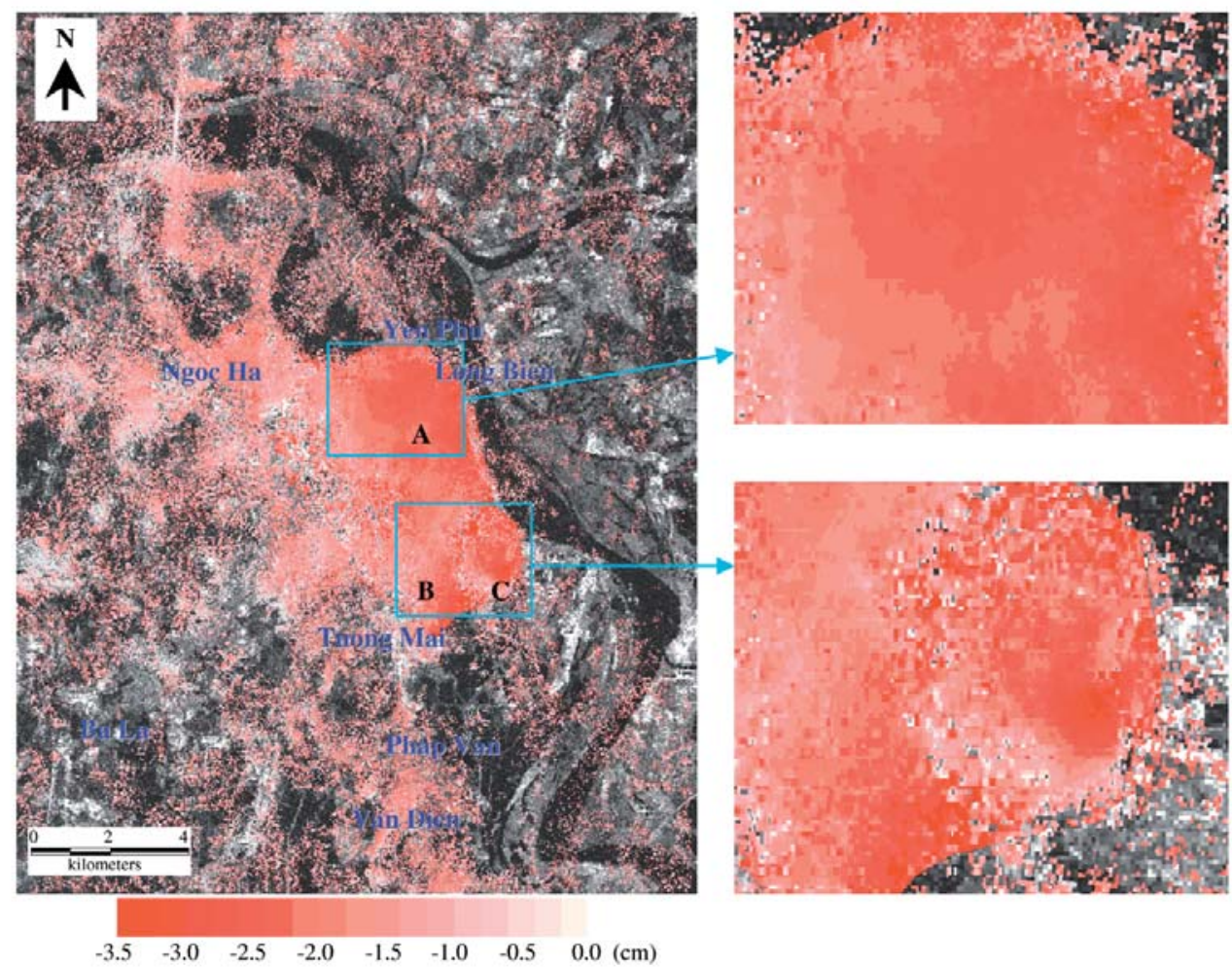

Figure 9. Annual rate of subsidence during the period 1995-1998. Drawn by GRASS 6.0.

we have the relation between the change phase $\Delta \varphi$ and the change of distance $\Delta r$ as follows:

$$
\Delta r=\frac{\lambda}{4 \pi} \Delta \varphi=(\lambda / 2)(\Delta \varphi / 2 \pi)
$$

Figure 6 shows the change phase $\Delta \varphi$. This type of image is called the differential interferogram. One color cycle or one "fringe" equals to $2 \pi$ radians and each fringe represents the change of distance by a half of wavelength. One fringe in Figure 6 corresponds to change by $11.76 \mathrm{~cm}$ in distance along the line of sight as the wavelength of JERS-1 L-band pulse is $23.513 \mathrm{~cm}$. It is notable that the change phases are clear in the urban area of Hanoi City corresponding to the area of high coherence shown in Figure 5(d), especially remarkable in three areas A, B and C while the phases are very noisy in the Red River and the vegetated area outside of the urban area corresponding to the area of low coherence.

\subsection{Estimation of subsidence}

Because Hanoi City is located within a stable continental plate far from the plate boundaries, we considered that the change phase detected in the urban area of Hanoi City is mainly caused by subsidence due to compaction of unconsolidated sedimentary layers. Assuming that there has been no horizontal displacement, we estimated the vertical displacement $\Delta h$ by

$$
\Delta h=\Delta r / \cos \theta
$$

where $\theta$ is the look angle of JERS-1 at the center of image $\left(\theta \approx 39^{\circ}\right)$ and $\Delta r$ is the change of distance along the line of

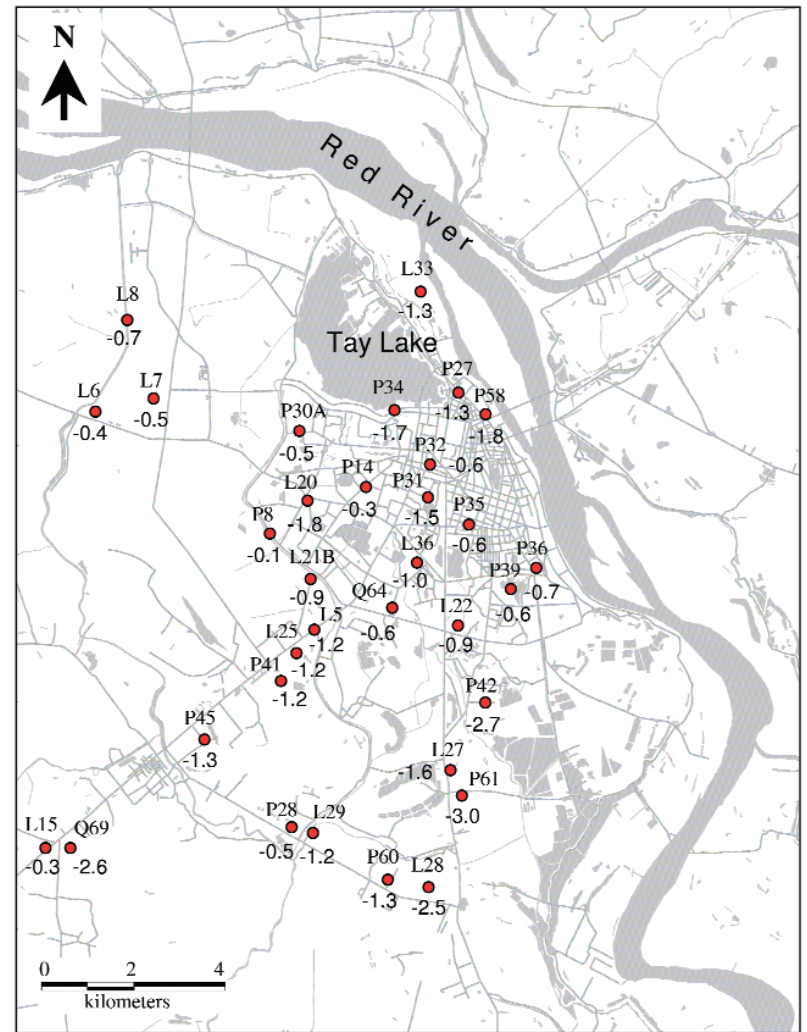

Figure 10. Locations of benchmarks listed in Table 1. Numerals represent annual rates of subsidence revealed by leveling survey in the period 1994-1995. 
Table 1. Two sets of leveling survey data.

\begin{tabular}{|c|c|c|c|}
\hline \multirow[t]{2}{*}{ Benchmark } & \multicolumn{2}{|c|}{$\begin{array}{l}\text { Rate of subsidence } \\
(\mathrm{mm} / \mathrm{y}) \text { Sites }\end{array}$} & \multirow[t]{2}{*}{ Sites } \\
\hline & 1994-1995 & 1988-1995 & \\
\hline L1 & 0 & 0 & Lien Mac \\
\hline L3 & 1 & 0 & Lien Trung \\
\hline L8 & 7 & 2 & Co Nhue \\
\hline L5 & 12 & 6 & Nhon \\
\hline L6 & 4 & 4 & Cau Dien \\
\hline L7 & 5 & 5 & Mai Dich \\
\hline L10 & 6 & 1 & An Khanh \\
\hline P44 & 7 & 2 & Tay Mo \\
\hline L12 & 6 & 1 & Hoang Van Thu \\
\hline L15 & 3 & 4 & $\mathrm{Ba} \mathrm{La}$ \\
\hline L19 & 7 & 3 & Ngo Sy Lien \\
\hline L20 & 18 & 21 & Thanh Cong \\
\hline Q64 & 6 & 9 & Y Khoa \\
\hline L21B & 9 & 6 & Cau Moi \\
\hline L22 & 9 & 12 & Vong \\
\hline L24 & 2 & - & Luong Yen \\
\hline $\mathrm{L} 25$ & 12 & 8 & Ha Dinh \\
\hline L26 & - & 19 & Cau Dau \\
\hline P60 & 13 & - & Van Dien \\
\hline Q69 & 26 & 21 & $\mathrm{Ba} \mathrm{La}$ \\
\hline $\mathrm{DL}$ & 5 & - & Do Lo \\
\hline L27 & 16 & 35 & Phap Van \\
\hline P61 & 30 & - & Phap Van \\
\hline L28 & 25 & 8 & Van Dien \\
\hline L29 & 12 & 19 & Cau Buou \\
\hline P28 & 5 & 14 & Cau Buou \\
\hline L33 & 13 & - & Tu Lien \\
\hline P14 & 3 & 3 & Giang Vo \\
\hline P8 & 1 & 5 & Lang \\
\hline L36 & 10 & 11 & Kim Lien \\
\hline $\mathrm{P} 41$ & 12 & 8 & Ha Dinh \\
\hline P36 & 7 & 9 & Luong Yen \\
\hline P31 & 15 & 9 & Ngo Sy Lien \\
\hline $\mathrm{P} 27$ & 13 & 8 & Yen Phu \\
\hline P30A & 5 & 3 & Ngoc Ha \\
\hline P32 & 6 & - & Hoang Dieu \\
\hline P35 & 6 & 14 & Thien Quang \\
\hline P39 & 6 & 1 & Thanh Nhan \\
\hline P42 & 27 & 44 & Tuong Mai \\
\hline $\mathrm{P} 45$ & 13 & 9 & Van Yen \\
\hline P34 & 17 & 9 & Ba Dinh \\
\hline P58 & 18 & 9 & Long Bien \\
\hline
\end{tabular}

Table 2. Comparison of leveling data with DInSAR data. The annual rate of subsidence estimated by DInSAR analyses were sampled at ten benchmarks.

\begin{tabular}{|l|c|c|c|}
\hline \multicolumn{1}{|c|}{ Sites } & Benchmark & $\begin{array}{c}\text { Leveling } \\
(94-95) \\
(\mathrm{cm} / \mathrm{y})\end{array}$ & $\begin{array}{c}\text { DInSAR } \\
(95-98) \\
(\mathrm{cm} / \mathrm{y})\end{array}$ \\
\hline Yen Phu & P27 & -1.3 & -2.55 \\
\hline Long Bien & P58 & -1.8 & -2.18 \\
\hline Ba Dinh & P34 & -1.7 & -1.80 \\
\hline Ngo Sy Lien & P31 & -1.5 & -1.73 \\
\hline Thien Quang & P35 & -0.6 & -1.84 \\
\hline Thanh Nhan & P39 & -0.6 & -1.18 \\
\hline Luong Yen & P36 & -0.7 & -0.80 \\
\hline Giang Vo & P14 & -0.3 & -0.89 \\
\hline Ngoc Ha & P30A & -0.5 & -1.08 \\
\hline Y Khoa & Q64 & -0.6 & -0.89 \\
\hline
\end{tabular}

$\begin{array}{lllllll}-3.0 & -2.5 & -2.0 & -1.5 & -1.0 & -0.5 & 0.0\end{array}$

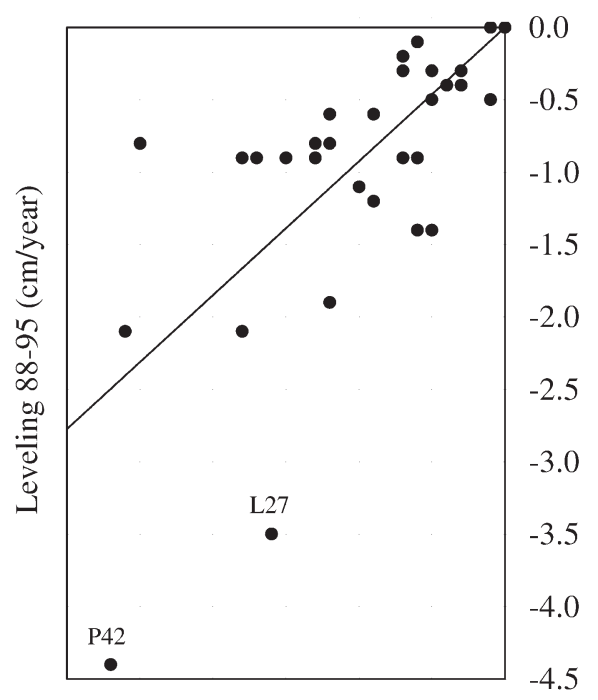

Leveling 94-95 (cm/year)

Figure 11. Correlation between subsidence rates estimated from leveling data in two periods 1988-1995 and 1994-1995 based on the data listed in Table 1. Correlation coefficient : 0.679. Best fit regression line : $y=0.92 x+0.00$.

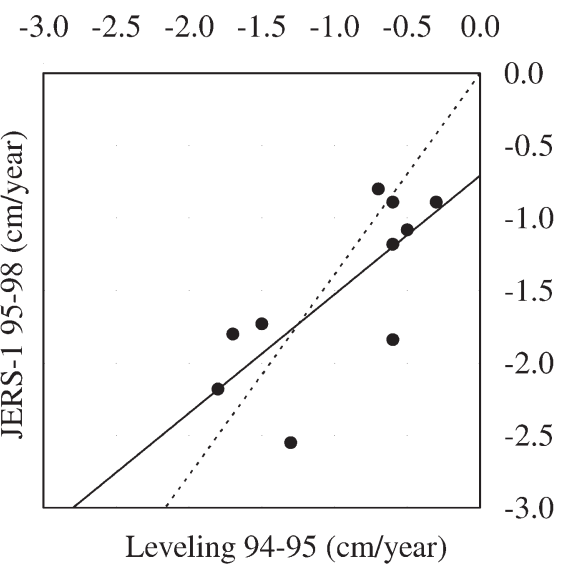

Figure 12. Correlation between subsidence rates derived from leveling survey in the period 1994 - 1995 and DInSAR analysis of images acquired in 1995 and 1998. Correlation coefficient : 0.75. Best fit regression line (solid line) : $y=0.82 x-0.71$. Best fit line passing through the origin (broken line) : $y=$ $1.39 x$.

sight. Then one fringe in Figure 6 corresponds to the vertical displacement of $15.13 \mathrm{~cm}$. Figure 7 shows the spatial distribution of estimated subsidence drawn by using the GRASS 6.0 GIS software (Neteler and Mitasova., 2002). A large amount of subsidence appears in the areas labeled A (about $8.0 \mathrm{~cm}$ ), B (about $9.0 \mathrm{~cm}$ ) and $\mathrm{C}$ (about $10 \mathrm{~cm}$ ). We observed the detail trend of subsidence in two profiles across the areas A, B and C. Figure 8 shows spatial variations along the lines $X X^{\prime}$ and $Y Y^{\prime}$ in which the distance is measured from the bank west of the Red River towards $\mathrm{N} 60^{\circ} \mathrm{E}$ direction. In the profile XX' the subsidence is clearly observed in the urban area of $0 \mathrm{~m}-3000 \mathrm{~m}$ in 
distance from the bank. The values scatter widely in the east side of the $0 \mathrm{~m}$ point including the Red River and the vegetated area belonging to Gia Lam district. The profile $\mathrm{YY}^{\prime}$ passes through the area labeled B and C. Two peaks of subsidence appear around areas B and $\mathrm{C}$. The subsidence reaches about 9.0 $\mathrm{cm}$ in the area $\mathrm{B}$ and about $10 \mathrm{~cm}$ in the area $\mathrm{C}$. In both profiles the subsidence is clearly detected in the urban area of Hanoi City, while data are scattered widely in the Red River and the suburbs outside of clear subsidence. The scatter of data reflects the decorrelation of the second pair of images due to water and vegetation.

Further, we calculated the annual rate of subsidence $\Delta v$ during three years from 1995 to 1998 by

$$
\Delta v=\frac{\Delta r}{T \cos \theta}
$$

where $T$ is the time interval of the second image pair, i.e. $T=3$ years. Figure 9 gives the spatial distribution of annual rate of subsidence displayed by GRASS 6.0. The highest rate of about $2.7 \mathrm{~cm} /$ year appears near the west bank of the Red River and the rate decreases westwards. Two sites of subsidence appear around areas $\mathrm{B}$ and $\mathrm{C}$ with the rate of about $3.0 \mathrm{~cm} /$ year and 3.3 $\mathrm{cm} /$ year respectively.

Referring to the distribution of water supply stations shown in Figure 2, we consider that the high rate subsidence in the area A is deeply related to the water pumping at big stations such as Yen Phu and Ngo Sy Lien. Further, it is notable that remarkable subsidence is additionally found at two places around Tuong Mai (the area labeled B) and around Minh Khai (the area labeled C) in the southern part of the city. The subsidence near Tuong Mai may be also related to a big water pumping station. However we can not discuss further the spatial relationship between the area of subsidence and the water supply stations, because the three-dimensional structure of unconsolidated sediments has not yet been revealed enough to simulate the hydrogeological behavior of underground water.

\section{Discussion}

Raucoules and Carnec (1999) analyzed ERS1/2 C-band images over Hanoi City and detected about a half fringe of differential interferometric phase, i.e. $1.5 \mathrm{~cm}$ in vertical movement in two periods: 6 months and two years. However because of decorrelation of ERS1/2 on the study area, the detail of subsidence was not found clearly. The present analysis of JERS-1 SAR L-band images revealed the spatial distribution of subsidence in the period 1995-1998 more clearly than Raucoules and Carnec (1999). We compared results mentioned above with leveling surveying data to make sure the reliability of the present analysis.

The leveling surveys were carried out three times in and around Hanoi City during the period from 1988 to 1995 by the
Northern Hydrogeological Engineering Geological Division. Table 1 summarizes the annual rate of subsidence during the periods from 1988 to 1995 and from 1994 to 1995 (Nguyen Van Dan., 1995). Figure 10 shows the sites of benchmarks and subsidence rates during the period 1994-1995 shown in Table 1. The result of leveling survey shows that most of the urban area and its vicinity subsided at a rate of $1 \mathrm{~cm} /$ year and more. The subsidence over $1 \mathrm{~cm} /$ year is observed in the area extending from the center of city toward the south. For example, the subsidence rate is high at L20 (Thanh Cong: $1.8 \mathrm{~cm} /$ year), P42 (Tuong Mai: 2.7 cm/year), L27 (Phap Van: $1.6 \mathrm{~cm} /$ year) and Q69 (Ba La : 2.6 $\mathrm{cm} /$ year).

Figure 11 illustrates the correlation between leveling data in two periods 1988-1995 and 1994-1995 based on the data listed in Table 1. There is a significant correlation between two data. The correlation coefficient is 0.679 and the best fit regression line is $y=0.92 x+0.00$. This indicated that the subsidence had continued during the period of 1988 to 1995 . Very large subsidence at P42 (Tuong Mai) and L27 (Phap Van) before 1994 might be due to the large amount of water exploitation at neighboring pumping stations (See Figure 2). Considering the scattering of data, it is most likely that there is a considerable change in the rate of subsidence during the period from 1988 to 1995.

For quantitative validation of correlation between two measurements: leveling data and DInSAR data, 10 leveling points were sampled within the area where the annual rate of subsidence is estimated by DInSAR analyses (See Table 2). Figure 12 shows the correlation between subsidence rates derived from leveling survey in the period 1994 - 1995 and DInSAR analysis of images acquired in 1995 and 1998. It is noted that we used leveling data in the period 1994 - 1995 because the leveling data in the period 1995 - 1998 was not available. There is a significant correlation between two data. Correlation coefficient is 0.75 . Best fit regression line is $y=0.82$ $x-0.71$ while the best fit line passing through the origin is $y=$ $1.39 x$.

The subsidence was detected from DInSAR only in a small part of Hanoi City area and reliable DInSAR data was absolutely absent in its outskirts covered with water and vegetation. Although leveling surveys detected a high rate of subsidence in the southern part of Hanoi City (Phap Van, Van Dien, or Ba La), we could not detect subsidence in the area because of low coherence. Besides, the survey benchmarks were not uniformly distributed all over the city and there were few benchmarks in the center and in the south east of the city. Therefore we should note that the above comparison of JERS-1 with leveling survey is not complete. However, as there is a fairly good correlation within the limited data, we concluded that the present analysis can detect the subsidence with accuracy enough to discuss the spa- 
tial variation of subsidence at least in the urban area.

\section{Conclusion}

We applied the differential InSAR method to three JERS-1 SAR images acquired on 1995/08/05, 1995/09/18 and 1998/09/22 in order to detect the subsidence of Hanoi City. Assumption that the interferogram for two SAR images acquired in 1995 indicates the topographic phase and interferogram for images acquired in 1995 and 1998 includes the deformation phase. The subsidence was detected in the urban area with accuracy enough to discuss the spatial variation of subsidence. The estimated rate of subsidence is approximately $2.7 \mathrm{~cm} /$ year to 3.3 $\mathrm{cm} /$ year at places related to the water supply station such as Yen Phu, Ngo Sy Lien and the southeast of the city near Tuong Mai and Minh Khai. Because of low coherence, we could not clearly detect subsidence in the southern Hanoi such as Phap Van, Van Dien and $\mathrm{Ba} \mathrm{La}$ and suburbs covered with water and vegetation. Thus the present analysis of JERS-1 SAR L-band images revealed the spatial distribution of subsidence in the period 1995-1998 more clearly than Raucoules and Carnec (1999). The results prove that JERS-1 L- band images are usable to detect the gradual vertical displacement of few centimeters per year even in the area of high humidity.

\section{Acknowledgement}

We are very grateful to reviewers for carefully reviewing the paper and providing constructive comments, which helped us to improve the final manuscript. We would like to thank Mr. Susumu Nonogaki for critical discussions. The first author acknowledges Japanese government (Monbukagakusho) for awarding scholarship.

\section{References}

Costantini, M. (1998) A novel phase unwrapping method based on network programming. IEEE Transactions on Geoscience and Remote Sensing, vol. 36, no. 3, pp.813-821.

Ferretti, A., Prati, C. and Rocca, F. (2000) Nonlinear subsidence rate estimation using permanent scatters in differential SAR interferometry. IEEE Transactions on Geoscience and Remote Sensing, vol.38, no.5, pp. 2202-2212.

Gabriel, A. K. and Goldstein, R. M. (1989) Mapping small elevation changes over large areas: Differential radar interferometry, Journal of Geophysical Research, vol.94(B), no. 7, pp. 91839191.

Goldstein, R. M., Zebker, H. A. and Werner, C. L. (1988) Satellite radar interferometry: Two-dimensional phase unwrapping. Radio Science, vol. 23, no. 4, pp. 713-720.

Goldstein, R. M., Engelhardt, H., Kamp, B. and Frolich, R. M. (1993) Satellite radar interferometry for monitoring ice sheet motion: Application to an Antarctic ice stream. Science, vol. 262, no. 5139, pp.1525-1530.

Honda, K., Canisius, J. and Tokunaga, M. (2003) Detection of volcanic deposits on Mount Mayon using SAR Interferometry. Geocarto International, vol. 18 no. 3, pp.15-19.

Madsen, S. N. and Zebker, H. A. (1998) Imaging radar interferometry. Principles and Applications of Imaging Radar, Manual of Remote Sensing, 3rd edition, Vol. 2, American Society for Photogrammetry and Remote Sensing, pp.359-380.

Neteler, M. and Mitasova, H. (2002) Open Source GIS: A GRASS GIS Approach. Kluwer Academic Publishers, Boston, 434 p.

Nguyen Trung Thong and Nguyen Van Dan (2005) Report of Investigation of Groundwater's Quality of Hanoi. Northern Hydrogeological Engineering Geological Division, Ministry of Science and Technology, Vietnam, 54 p., (in Vietnamese).

Nguyen Van Dan (1995) Report of Hydro-geological Research and Subsidence in Hanoi. Northern Hydrogeological Engineering Geological Division, Ministry of Science and Technology, Vietnam, 19p., (in Vietnamese).

Raucoules, D. and Carnec, C. (1999) DEM derivation and subsidence detection on Hanoi from ERS SAR interferometry. Proceedings of 2 nd International Workshop on ERS SAR Interferometry: Fringe'99, 6 p.

Rott, H., Mayer, C. and Siegel, A. (2000) On the operational potential of SAR interferometry for monitoring mass movements in Alpine areas. Proceedings of EUSAR2000, Munich, Germany, pp. 43-46.

Wegmuller, U., Werner, C., Strozzi, T. and Wiesmann, A. (1999) Land subsidence mapping with ERS interferometry: Evaluation of maturity and operational readiness. Proceedings of $2 n d$ International Workshop on ERS SAR Interferometry: Fringe'99, 9 p.

Wegmuller, U., Werner, C., Strozzi, T. and Wiesmann, A. (2001) GAMMA Software documentation. Gamma Remote Sensing, $44 \mathrm{p}$.

Wegmuller, U., Charles L. W, Tazio, S. and Andreas, W. (2002) Phase Unwrapping with GAMMA ISP, Technical Report, Gamma Remote Sensing, 12 p.

Zebker, H. A., Rosen, P. A., Goldstein, R. M., Gabriel, A. and Werner, C. L. (1994) On the derivation of coseismic displacement fields using differential radar interferometry: The Landers earthquake. Journal of Geophysical Research, vol. 99(B), no. 10, pp.19617-19634. 
要 旨

JERS-1 の SAR インターフェロメトリによって検出されたハノイ市の地盤沈下の空間分布

:トラン バン アン*・升本 眞二**ベンカテッシュ ラガワン**・塩野 清治*

ベトナムの首都ハノイ市は, Red Riverの氾濫原に位置し, 平均標高は $20 \mathrm{~m}$ 以下である. ハノイ市では人口の急激 な増加に伴う地下水の汲み上げにより，顕著な地盤沈下が起こっている．地盤沈下の状況は測量でモニタリングされ てきたが，広域で高密度な測量を実施するには時間と労力が必要である。そのため，本研究ではそれを補う方法とし て SAR 差分インターフェロメトリを利用した。都市域での地盤沈下の空間的な広がりを検出するために，3つの異な る時期に収集したイメージから地形变化を求める3-パス差分インターフェロメトリ法を採用した. 2 つインターフ エロメトリックペア（インターフェログラム）を作成するために 1995 年〜 1998 年にえられた 3 つの JERS-1 の L バ ンドの SAR イメージを用いて, 市街地と郊外のおよそ $400 \mathrm{~km}^{2}$ の地域を解析した. Red River, Tay 湖および郊外の植 生のある地域における差分インターフェロメトリックフェーズにはノイズが多かったが, 市街地では地盤変動の特徴 を明瞭に検出できた。地盤沈下速度は Tay 湖近くの地域で $2.7 \mathrm{~cm} /$ 年, 市街地の南東部の Minh Khai では $3.3 \mathrm{~cm} /$ 年で あった。この結果は 1994 年〜 1995 年の Tay 湖や Red River 周辺の水準測量で得られた急激な地盤沈下の測量結果 (1.3-1.8 cm/年) と矛盾しない. 市の南部ではJERS-1 データではコヒーレンスが低いために, 測量データで著しい地 盤沈下が観測されている Phap Van やV Van Dien 周辺での地盤沈下は抽出できなかった. 以上の結果から，コヒーレン スの高い地域については，Lバンドイメージはハノイ市の地盤沈下のモニタリングに実用できると結論した。

キーワード：リモートセンシング，水準測量，Lバンド，DInSAR、3-パス法

* 大阪市立大学大学院理学研究科

**大阪市立大学大学院創造都市研究科 